Article

\title{
The Social Sustainable City: How to Involve Children in Designing and Planning for Urban Childhoods?
}

\author{
Gro Sandkjaer Hanssen \\ Norwegian Institute for Urban and Regional Research, Oslo Metropolitan University-OsloMet, 0130 Olso, Norway; \\ E-Mail: groha@oslomet.no
}

Submitted: 16 August 2018 | Accepted: 4 October 2018 | Published: 24 January 2019

\begin{abstract}
In many countries, cities are expected to stimulate compact city development by the government, while at the same time develop healthier and more social sustainable cities. In Norway, national policy and planning regulation aim at stimulating a development that ensures active urban childhoods. In order to ensure this, the Planning and Building Act ensure particular participation rights for children and youth in the planning process. In this article, we will present how these rights are understood and implemented in practice. Then we will discuss how local government can enable children to participate in a meaningful way and where their input actually contributes to the plans and urban design being developed. This last discussion will be elaborated by studying a case about the Children Track Methodology.
\end{abstract}

\section{Keywords}

childhood experience; children; Children Track Methodology; participation rights; planning; urban design

\section{Issue}

This article is part of the issue "The Transformative Power of Urban Planning through Social Innovation", edited by Torill Nyseth (UiT, The Arctic University of Norway, Norway) and Abdelillah Hamdouch (University of Tours, France).

(C) 2019 by the author; licensee Cogitatio (Lisbon, Portugal). This article is licensed under a Creative Commons Attribution 4.0 International License (CC BY).

\section{Introduction}

In many European countries today, national policies aim to encourage a more compact city development while at the same time expecting the cities to become healthier and more social sustainable cities. Lately, the UN and EU Urban Agenda have spurred a more active national policy-development on sustainable cities, which also recognise the importance of citizen involvement and local knowledge (Derr \& Tarantini, 2016; UN, 1989; UNICEF, 2014). This tendency can also be observed in Norway. In order to develop more social sustainable cities and neighbourhoods, national planning policy and planning regulation have, for over 30 years, included aims of active urban childhoods. In order to ensure this, the Norwegian Planning and Building Act ([PBA], 2008) includes specific legal rules regarding children and youth.

The PBA has both procedural and substantial elements. The procedural requirements imply that municipalities must involve children and young people in local planning processes. Furthermore, there are also more substantial requirements, as one of its main purposes (§ 1-1) is that planning, according to the PBA, is to ensure the upbringing conditions for children and youth.

The article presents how these rights are understood and how cities and municipalities implement them in practice. Then the article discusses how local government can facilitate the involvement of children and youth in a meaningful way, where their input actually contributes to the plans and urban design being developed. This last discussion will be elaborated by studying casemunicipalities using Children Track Methodology.

The data material, including both survey material from local planning executives and in-depth interviews with municipal actors and stakeholders, stems from a research evaluation of the Norwegian PBA. The article sheds light on how a country, having had an aim of ensuring the concerns of children and youth in planning for over 30 years, is able to do this in practice, and how new methodology can contribute. 


\section{Theoretical Considerations}

The PBA has both procedural and substantial elements, more specifically participation rights and an explicit aim that planning ensures the concerns and needs of children and youth (active childhoods). Firstly, the article presents some of the theoretical arguments for these elements.

\subsection{Theoretical Arguments for Participation Rights for Children and Youth}

The 1989 UN Convention on the Rights of the Child states that a child's view must be taken into account in all matters that affect her/him (Cele \& van der Burgt, 2015). The theoretical perspectives arguing for citizen involvement are many (Hanssen, 2013; Vestby \& Ruud, 2012). Firstly, in a more Schumpeterian view, where participation in elections is essential, an important argument for involving children and youth in planning is based on a compensatory justification. As children and adolescents under the age of 18 do not have the right to vote, they should be compensated for that through direct participation. In addition, children and youth are often unable to formulate or raise their claims on their own (Bringeland, 2017; Ministry of Environment, 2009). Secondly, a more participatory democracy strand of the literature (Pateman, 1970, Fung \& Wright, 2001) emphasises the democratic principle that all interests and groups should be heard in planning. By channelling a broader array of interest into local policy-making, this will result in a more legitimate urban and local development (input legitimacy; see Scharpf, 1999). Here, children and youth are relevant groups to involve. A third perspective focuses on the effect for individual development and empowerment, stressing that the involvement of children and youth will form them as empowered citizens who are engaged in their communities (Lynch, 1977; Pateman, 1970; Wilks \& Rudner, 2013). Participation can, thus, be considered as a lesson in democracy, as Pateman (1970) was concerned with. This is expressed as an important argument by the Planning Law committee in Norway, while preparing the Law, stating that: "The education of children and youth in the role of citizens of society should also be emphasized" (NOU, 2003, p. 171). This is mirrored in the Education Act (1998), where the $\S 1-1$ states that children should "develop knowledge, diligence, and attitudes in order to enable them to live and to participate in community work and community" and that "[the children] shall have a...right to participation" (Stray, 2014). The new main part of the (national) curriculum emphasises the development of democratic competence, stating that democracy and citizenship as an interdisciplinary theme in school will provide pupils with knowledge of the conditions, values, and rules of democracy and enable them to participate in democratic processes (NOU, 2015; see also Meld. St. 28, 2016).

Also from social-policy perspectives and placedevelopment perspectives, many argue for increased participation by children and youth (Gehl, 1971, 2010; Vestby \& Ruud, 2012). The involvement of children and youth can help to strengthen their self-esteem, which is important from a public health perspective. Others emphasise that inputs from children and young people contribute with unique knowledge about children's sense of place and their use of their everyday-surroundings. These inputs can inform and shed light on different concerns in the planning processes and provide more informed policy decisions. Hovind (2014) emphasises that it is important to bring children into the planningand decision-making processes, as they are often an important target group for social sustainable urban policymaking. Jan Gehl-who is known for Life between the Houses (1971) and Cities for People (2010) believes that we can influence citizens to use of the city through physical planning. Thus, it is important to obtain information from residents about how they want to use the city and how the physical environment should look like (Lynch, 1977). Much of the research literature emphasises that children are able to point out problems that must change in a society, and their views and assessments are important to channel into local planning- and decision-making (Bringeland, 2017; Buss, 1994; Cele \& van der Burgt, 2015; Derr, 2015; Derr \& Tarantini, 2016). In addition, children and youth differ from adults and often actively use the local community and therefore want more knowledge about how their local environment should be facilitated. This is also emphasised in the international urban development discussion, which argues for greater involvement of children in urban planning and physical environment design because "built environment solutions developed through engagement with children, parents/carers, and the wider community will be richer, while the process itself will directly benefit those who participate" (Arup, 2017, p. 55). Thus, channelling the knowledge and experience they possess can lead to better results and a more appropriate city, location, and service development (output legitimacy; see Scharpf, 1999).

\subsection{Active Urban Childhoods: Theoretical Arguments for Planning That Ensure the Concerns and Needs of Children and Youth}

The theoretical arguments for ensuring the needs and concerns of children in planning are primarily based upon the wish of developing children-friendly cities and places. In the discussion of social sustainable cities, much of the literature focuses on how politics, in order to strengthen social equality, must address citizens while they are young. Firstly, the increased focus and institutionalisation of health promotion and equality in health contribute to an increased focus on early prevention, life quality, and physical and social active childhoods (Henriksen, 2014; Hofstad, 2018). Physical activity has been shown to be important for children's immediate social, mental, and physical health, as well as benefi- 
cial to health across the lifespan (Boreham \& Riddoch, 2001; Veitch et al., 2006). Thus, a children-friendly city can have a preventive effect on increasing social cleavages. Jerome Frost, Arup's Global Planning and Cities leader, states:

The choices we make in the built environment can help to ensure children are given respect, fair treatment, a healthy life, and the best chances of tackling the challenges of tomorrow. By highlighting children's needs, we will be helping to solve other urban challenges, leading to cities that are better for everyone. (Arup, 2017, p. 7)

Secondly, the physical environment is also essential for the development and independence of children and adolescents (Hovind, 2014; Freeman \& Tranter, 2011). Independent mobility in a local environment is crucial for a child's development and physical activity, contributing to overall health and well-being (Fagerholm \& Broberg, 2011). It is therefore important that there are good and suitable outdoor areas for children and young people which are sufficiently safe, for children to unfold, develop self-esteem, and develop a sense of belonging to the place. Inclusive design and planning are found to be essential to encourage children's spatial mobility in public spaces (Haider, 2007). Here, it is important to emphasise that a playground is not enough to ensure children's development. As Arup (2017, p. 17) states:

Children's infrastructure is the network of spaces, streets, nature, and interventions which make up the key features of a child-friendly city....By promoting connected, multifunctional, intergenerational and sustainable public spaces for cities, children's infrastructure can generate a substantial range of benefits for all urban citizens. A key focus area for children's infrastructure is the streets and the spaces in front of people's homes. On average, these make up at least $25 \%$ of a city's space and have the greatest potential to encourage everyday freedoms and social interaction. This means looking beyond just playgrounds and instead focusing on an intergenerational and multifunctional public realm that families and communities can enjoy together. Cities should aim to enhance a child's connection to nature through green and healthy environments. They should also influence and impact a child's everyday journeys, including routes to and from school or to and from community facilities such as youth centres, parks, leisure, and recreation areas.

Thirdly, due to the trend of compact city development and densification around public transport hubs, there is an increased concern regarding how densification effects urban childhoods (Arup, 2017). Public statistics show that one of the consequences of densification in Norway was a $12 \%$ decrease of playgrounds and recreational areas from 1999 to 2004 (Proposition 32, 2008). As a result, research shows that children and youth were less active in 2005 than in 1997 (Hovind, 2014). This inactiveness can, in the long run, result in diminished "health" for the individual and an increased cost on the public health budget.

However, in order to ensure the concerns and needs of children, spatial planning is not enough. A broader societal planning perspective is just as important, ensuring coordinated public services (schools, social care, etc). In order to safeguard the upbringing environment, it is also important to have a broader focus on the employment policy in the municipality, as parents are fundamental factors in their living conditions. Economy, work-places and living environment, health behaviour and the use of health services constitute factors that affect health, and which are unevenly distributed in the population (Hofstad, 2018). Hence, ensuring the concern for children is much related to social and economic planning, as well as land use planning (Hanssen, 2018).

\subsection{Theoretical Considerations: Local Knowledge That Can Be Produced by Involving Children}

One of the challenges of bringing the children's voice into local planning and policy processes is that they need to be translated into a "language" that fits the planningformat. According to Nonaka and Takeuchi (1995) conceptualisations, the tacit, silent, and non-articulated knowledge of the sense of place of children has to be articulated, expressed, and given a formal language-for example, as text or maps. Different methods exist for doing this, like workshops, digital "sim-city", "children tracks", and the like. Many of these methods function as translations of tacit knowledge to explicit knowledge (Nonaka \& Takeuchi, 1995). However, every translation process, mostly being done by adults, represents a risk of reducing the rich knowledge to a very "thin" type of knowledge. Thereby, the rich experiences of how local space is perceived by the children are at risk of being lost "in translation".

\section{How Does the Norwegian PBA Ensure the Involvement and Concerns of Children and Youth in Planning?}

Children and young people's ability to participate received stronger legal protection through the ratification of the UN Convention on the Rights of the Child in 1991 and was passed into Norwegian Law in 2003 (Ministry of Environment, 2009). Norway is thus obliged to comply with the UN Convention on the Rights of the Child in national law, including Article 12, which states that the child has the right to express his or her opinion on all matters relating to it and to emphasise her/his opinions. The article also includes children's participation in the wider sense, as active participants in society. The principles are reflected in the Norwegian PBA (2008), which included these concerns from 1985. 
In Norway, local authorities have extended local autonomy and wide discretion (Baldersheim \& Rose, 2014), although within the framework of national legislation. Local government has the main responsibility for land use planning and for broader societal planning, and the PBA is, therefore, a process-law, stating the rules-of-thegame without providing a strong direction for the output of planning.

When it comes to children and youth, the PBA has both procedural and substantial elements. The procedural requirements imply that municipalities must involve children and young people in local planning processes. The Norwegian PBA (2008) states that municipalities have an obligation to "ensure active participation from groups that require special facilities, including children and youth" (§ 5-1). Further, it is a statutory duty under the PBA that "the municipal council shall ensure that a special arrangement is established to safeguard the interests of children and young people in the planning" (PBA, 2008 , § 3-3, para. 3). Earlier, in 1985, the PBA stated that it had to be appointed a "children's representative", which was often a public planner. Since 2008, the municipalities are freer to choose what kind of arrangement they prefer.

Furthermore, there are also more substantial requirements in the PBA, as one of its main purposes ( $\S 1-1)$ is that planning, according to the PBA (2008), is to ensure the upbringing conditions for children and youth. ${ }^{1}$ To achieve good living environments and childhood conditions for children, the PBA gives the municipalities a right to require outdoor areas and playgrounds by means of "regulation provisions" in the detailed zoning-plans (detaljregulering). In § 12-7 they are entitled to include functional and quality requirements for buildings, facilities, and outdoor areas in the detailed zoning-plan, including requirements for ensuring the health, environment, safety, universal design, and children's special needs for play and outdoor spaces.

In the Impact Assessment Regulations (2017), section 21 on "Description of Factors that Can Be Impacted and Assessment of Significant Impact on the Environment and Society" states that the impact assessment should identify and describe the factors that may be affected and assess significant environmental and social impacts, including the upbringing conditions of children and adolescents. That description should include positive, negative, direct, indirect, temporary, lasting, shortterm, and long-term effects.

The PBA gives national authorities the instrument of national "planning guidelines", giving (vague) direction for local planning without steering them in detail. The national guideline for strengthening the interests of children and youth in planninghas existed since $1995 .^{2}$ This guideline goes further than the PBA. It emphasises the importance of assessing the consequences for children and young people in planning and construction work under the PBA $(2008,4 a, 4 b)$, preferably by highlighting the case by direct involvement (PBA, 2008, 4d). The guidelines also state that these interests must be strengthened. This implies that the considerations will get more impact through the development of guidelines and provisions in the plans for the extent and quality of areas and facilities of importance for children and young people, to be ensured in plans where children and young people are affected (PBA, 2008, 4c). In addition, the RPR has physical design requirements to ensure the consideration of children's and adolescent's upbringing conditions (PBA, 2008, 5a, 5d).

In the white paper NOU (2001, p. 196) the two dimensions-the procedural and substantial-are presented as being intertwined, as "their participation is crucial for, among other things, the development of the upbringing environment". Thus, from a holistic perspective, it is now understood that both the $\S 1-1$ about the purpose of the Act, $\S 5-1$ participation, the $\S 3-3$ about the special arrangement, and the more detailed requirements for investigative requirements - and possibilities to include regulation provisions-together have the potential to ensure open and (local) knowledge-based planning processes with the possibility of broad involvement of all concerned interests. This also applies to weak groups, and especially children and youth (Bugge, 2016). However, even if the institutional framework around local planning has this potential-it is not necessarily realised in practice. The next section will present results from empirical studies trying to map local practices.

\section{Data and Methods}

The data material stems from a large research evaluation of how the Norwegian PBA function as a framework for local, regional, and national planning. Here, 251 key actors are interviewed, including informants from three governmental levels, and informants from the private sector and civil society. Not all of them have been relevant for the subject of "children and youth", but the interview material gives us a broad and rich knowledge about local practices and perceptions. Many of the in-depth interviews about the situation of children and youth in planning have been conducted in the work of two master theses (Bringeland, 2017; Martinsen, 2018). The evaluation has also conducted a Questback-survey with the planning executives in all municipalities in Norway. Here, 202 of the 428 planning executives answered the survey, giving us a response rate of 47 . We also use DogAs survey (Hegna 2017) to municipalities. The data is used to map how municipalities work with regards to ensuring the involvement of children and youth in urban and local spatial planning. In addition, the qualitative interview data are used to illustrate the challenges regarding the systematic inclusion of children and also to identify the successfactors required to achieve a comprehensive, systematic, and meaningful way of including children and youth.

\footnotetext{
1 "Ivareta barn og unges oppvekstvilkår" in the original.

2 The Norwegian title is: "Rikspolitiske retningslinjer for barn og planlegging".
} 


\section{Mapping: Are Children and Youth Involved (and Their Concerns Ensured) in Urban Planning?}

As the previous section described, it is a statutory duty under the Norwegian PBA $(2008, \S 3-3$, para. 3) that "the municipal council shall ensure that a special arrangement is established to safeguard the interests of children and young people in the planning". Earlier, the PBA stated that the municipalities had to have a "children's representative", which was often a public planner. Thus, even if the PBA states that the municipalities must have a special arrangement, they are now freer to choose what kind of arrangement they prefer. But do all municipalities have such an arrangement? We asked the planning executives in the municipalities, and the results are presented below.

Figure 1 reveals a huge difference between smaller and larger municipalities when it comes to whether the legal requirement for a special arrangement ensuring the concerns of children and youth is introduced. It is introduced to a much lesser extent in small municipalities than in large municipalities. This pattern becomes even more visible when the municipalities are split into smaller categories according to size, as illustrated in the figure below.

Figure 2 shows a systematic increase in the percentage of municipalities that have a special arrangement for ensuring the interest of children and youth in planning, due to municipal size. As much as $91 \%$ of municipalities with more than 20,000 inhabitants have a permanent arrangement, while the percentage of municipalities with less than 2,000 inhabitants is 28 . In the qualitative interviews, this is explained by the lack of competence and capacity.

The argument that the people are closer to the councillors in small municipalities is to some extent valid for children and young people. Real participation by their side requires more systematic arrangement and facilitation. The variation by size is in accordance with what is found in previous studies of children and young peo-

Does your municipality have special arrangements that systematically ensures the concerns of children and youth in planning?

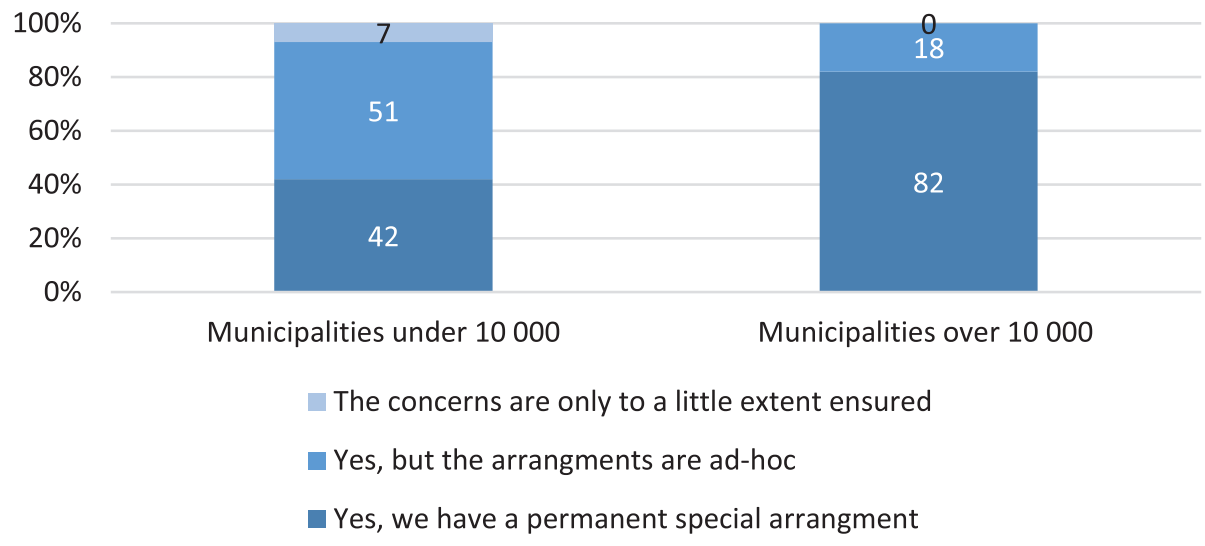

Figure 1. Special arrangements in the municipalities. Notes: Percentage; $N=202$, planning executives in municipalities; data from 2018.

Does your municipality have special arrangements that systematically ensures the concerns of children and youth in planning?

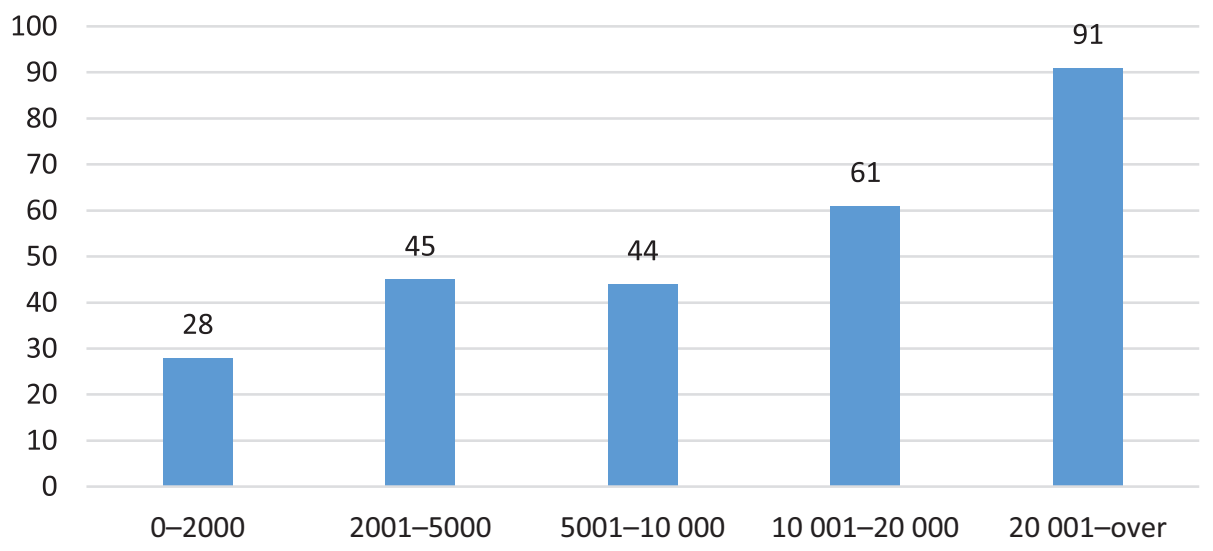

Figure 2. The percentages of municipalities that report that they have a permanent special arrangement-variation between different categories of size. Notes: Percentage; N = 202 planning executives in municipalities; data from 2018. 
ple's participation (Klausen et al., 2013; Knudtzon \& Tjerbo, 2009).

So, the municipalities that have established special arrangements, what types of arrangements are chosen, now that they are freer to choose? The figure below shows what the planning executives of the municipalities reported in the survey.

Figure 3 shows several interesting trends. Even though the requirement for "children's representative in planning" was removed in 2008, about $60 \%$ still have the function of the children's representative in planning matters. This can be considered a relatively large proportion. Children's representatives are most often municipal civil servants-often a planner or a public health coordinator, or from the school department, etc., and come up with ideas. Thus, it is a form of "advocacy" planning. Furthermore, around a quarter of the municipalities involve the children's and youth councils. However, the proportion is not significantly higher than we find in an evaluation from 2006 (Hanssen, 2006), where around $20 \%$ indicate that they involved children and youth councils in municipal planning processes. These councils are composed of representatives elected through the pupilscouncils at the schools and can be said to be more in line with the Planning Law committee's emphasis that "children and young people's participation must primarily come through children and young people's own involvement" (NOU, 2003, p. 251). This is also in line with the UN Convention of the Right of the Child, stressing that the view of the child must be taken into account (Cele \& van der Burgt, 2015; UN, 1989). Other Norwegian studies (Knudtzon \& Tjerbo, 2009) find that they function as important arenas for bringing the children's voices to the municipal council, connecting them to the ordinary decision-making processes. The councils are also an important "school in democracy", training children to be active citizens. Alparone and Rissotto (2001) find that youth councils represent the most widespread method in Ital- ian municipalities, in addition to participation in planning urban spaces. But also here, even if this method is characterised by direct participation, Alparone and Rissotto (2001) find that the adult administrator has a key role as the main promoter (and mediator) of children's participation experiences. They might also be gate-keepers. A UK-study shows that children that were involved in children-consultation initiatives in several UK cities were critical to the administrators for not taking their proposals into consideration (Woolley, Dunn, Spencer, Short, \& Rowley, 1999). What is more surprising is that only $5 \%$ report that they involve the schools systematically in overall planning processes. The extent to which municipalities have used children's tracks is also surprisingly low at only $4 \%$. This is consistent with previous studies, where $5 \%$ of municipalities report that they use children's track in planning in Hegna's (2017) study. A similar mapping in Sweden (Cele \& van der Burgt, 2015, p. 18) shows that here, the involvement of children is most often carried out by consultations via surveys, reference groups, and youth councils. These are more direct-participation models than the Norwegian "children's representative". Similar to the findings in Norway, only some of the municipalities in Sweden make use of "child-led walks" and maps (Cele \& van der Burgt, 2015, p. 18).

The widespread use of advocacy planning in Norway (children's representative) compared to direct participation models, is a worrisome finding. Studies call for updated skills for planners in interacting with children and understanding and translating their sense of space and place. Cele and van der Burgt (2015, p. 18) show that places are often objectified places and the manner in which children experience the same environments, both physically and emotionally, often directly contradicts the conceptions of planners.

Thus, this mapping shows that even if the legal framework requires the systematic involvement of children and youth, there is a large variation between the mu-

\section{The type of arrangements to be found in the municipalities}

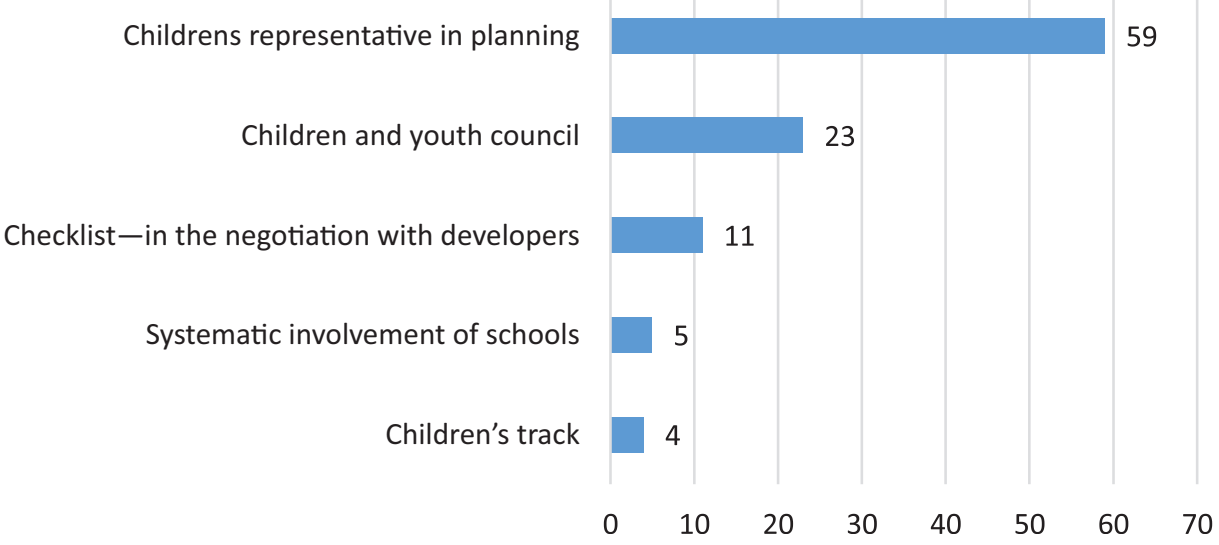

Figure 3. The type of arrangements that are found in the municipalities. Notes: Percentage (many alternatives allowed); $\mathrm{N}=159$; data from 2018. 
nicipalities regarding how these requirements are met in practice. Thus, there is great potential for more innovative ways of including children and youth in municipal planning practices. In the last section, we will show how a certain involving method, the children's track, is used. Then we discuss the strengths and pitfalls of the method.

\section{Children Track Methodology}

\subsection{Presentation of the Children Track Method}

Over the last decade, there has been a great deal of innovation in citizen involvement, spurred by digital development and GIS-technology. However, the Children Track Methodology is an old method from the 1970s that has experienced a revival due to digital development. Originally, the method ("Barnetråkk") was developed by a Norwegian planner in the 1970s (Gill, 2018), and after Norway's adoption of the UN Convention on the Rights of the Child in the late 1980s, the method was more frequently used. The method is easy; by using maps, children are to draw their axes and important places in their everyday-life, and also evaluate them. The axes show the route they take from home to school, or to the playground. And the symbols are different categories of use (play, football, hang around, etc.) and evaluation (a scary place, too much traffic, a nice place to play, etc.). The intention is to grasp the children's use and assessment of their neighbourhood.

In 2006, Children Track Methodology took the step from being a map-based method using paper maps, to becoming an online platform. The platform was given new impetus in 2016 after being updated and promoted by the Norwegian Centre for Design and Architecture (Gill, 2018), and made available for municipalities and schools to use free of charge. Thus, the method became much easier to use for the municipalities.

In the digital version, the map-registrations from each child are aggregated and visualised in maps with many registrations, as illustrated in Figure 4.

The map shows an aggregated summary of the "dots" the children have registered in the digital program, illustrating the places where they spend their leisure time in the neighbourhood. In the text, the planner has condensed many of the inputs related to specific places. For example, regarding the square in front of the city hall (upper, right), the text reads: "The Square in front of the City Hall is a place with a lot of activities, and the children like that. Many say that they hang around there, in the skate park, and meet friends. Several express that they need a bigger skate park". The comments to the red dots in the circles express that the children experience these two places as having heavy traffic, and do not feel safe here. Some of them have expressed that they want light regulation to be able to cross the streets safely.

The map from the children track registrations in Giske municipality shows the aggregated patterns from the children's own registrations. It shows, as red roads, the streets and pathways most of the children use. The violetcoloured areas are considered by the children to be "problem areas". The green colour represents the green areas where the children walk and play. The striped areas are places where the children have reported that they especially like spending time.

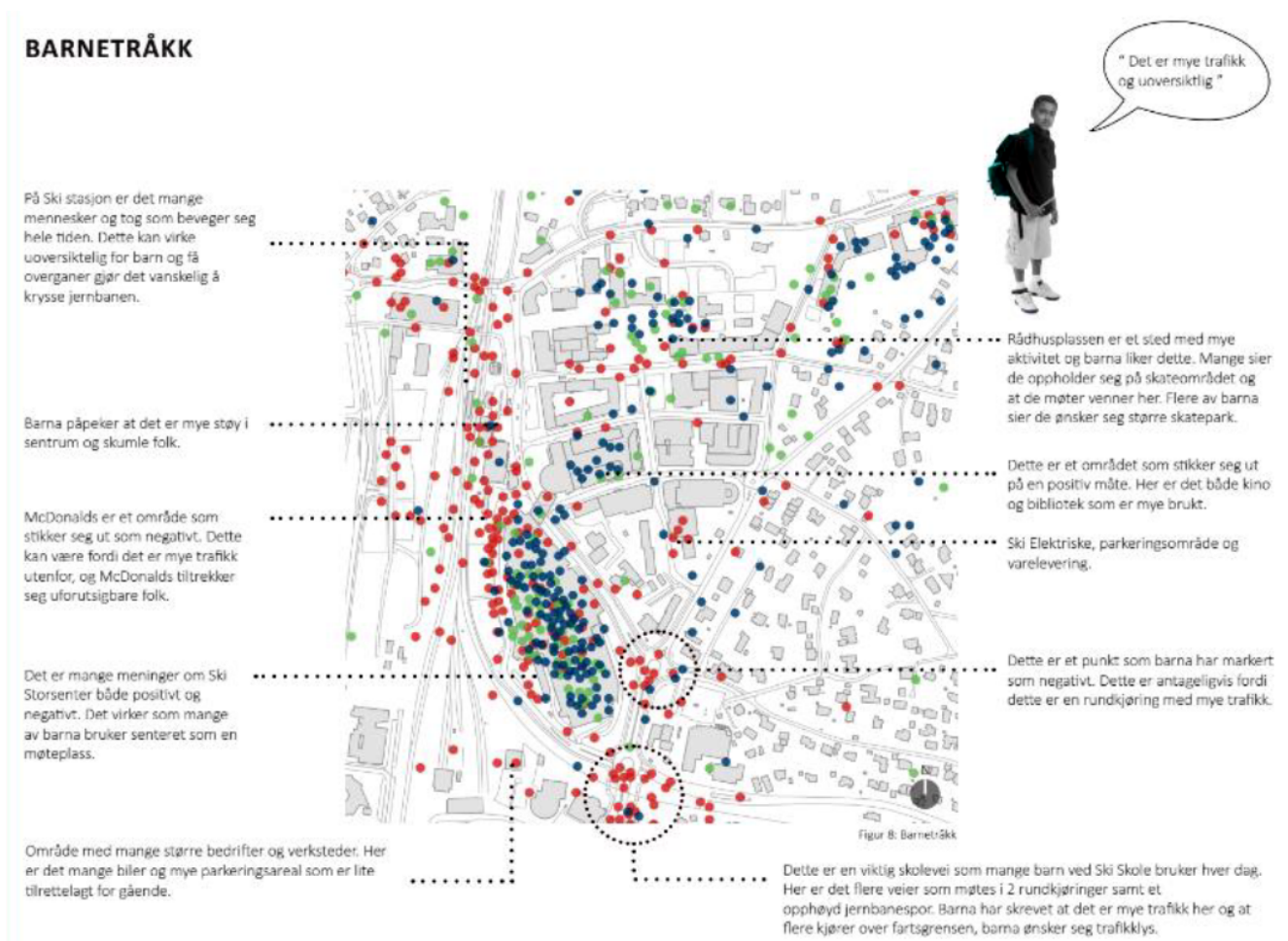

Figure 4. Illustration from the municipalities of Ski. Source: Ski Municipality, 2016. 
ArcGIS $\nabla$ Barnetråkk i Giske Kommune

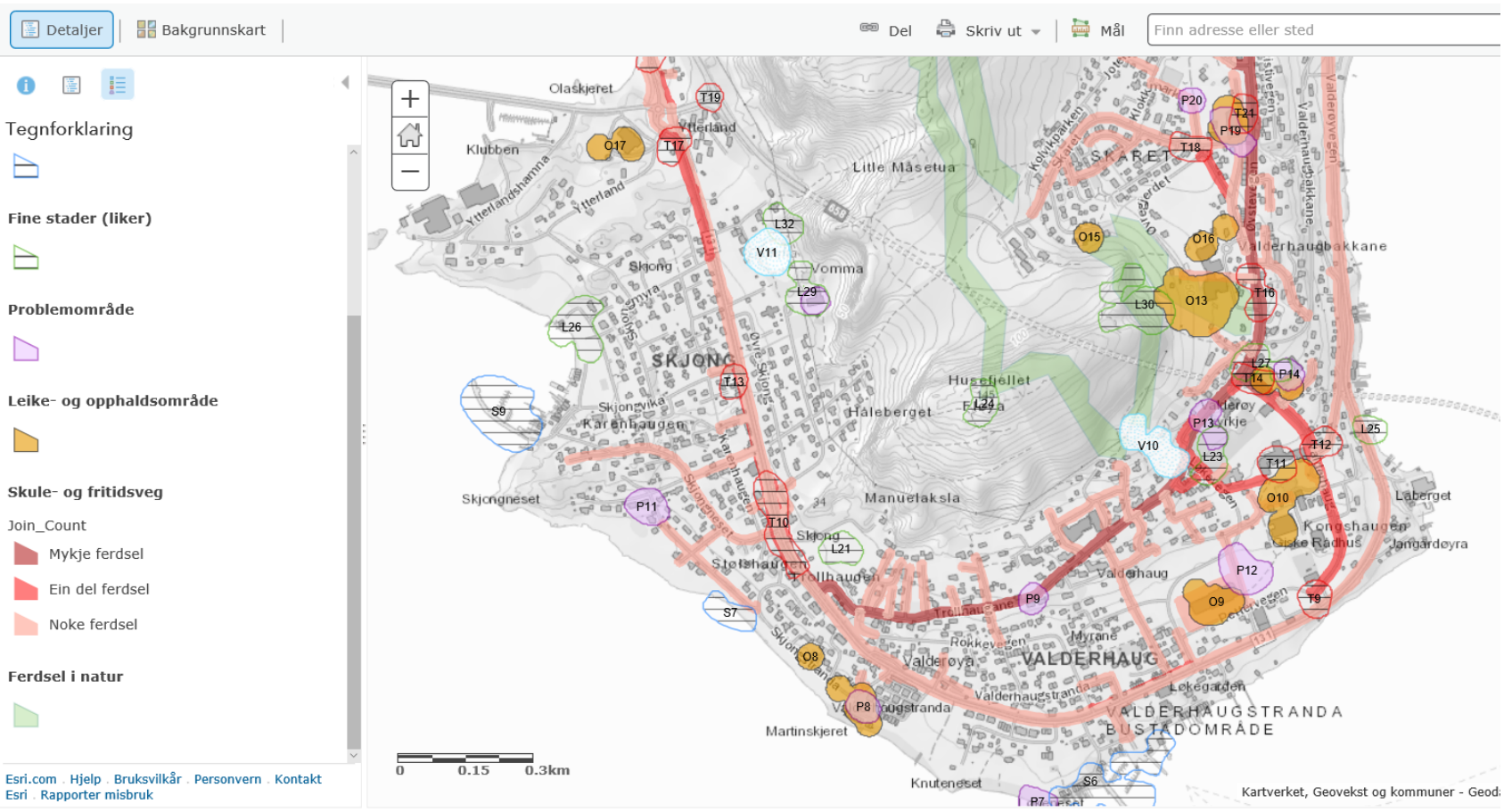

Figure 5. Illustration from the municipality of Giske (Giske Municipality, 2018).

Thus, the maps contain valuable information regarding the children's use of space, and also how they value the space (different qualities). How widespread is this practice? According to the mapping (see the section above), only $4 \%$ of the municipalities in our survey reported that they have systematically used this method. This corresponds to a similar survey from the year before (Hegna, 2017), finding that 5\% had reported the same. Far more municipalities have conducted a children's track less systematically. However, by conducting an OLS-regression analysis on DogAs survey (Hegna, 2017) we find the same variation due to the municipal size that we had previously found.

The regression analysis in Table 1 shows that municipality size has a significant effect, i.e., that it is primarily larger municipalities that use the method. In addition, the self-assessment of competence has a positive effect, i.e., they consider that their own municipality has the competence to carry out collaborative processes within municipal planning. In addition, there is a positive impact if they usually involve residents in detailed zoning plans. A culture involving residents is reflected in, and reinforced by, competence to conduct participatory processes and actual policies to include residents. However, even if the effects are significant, the model does not explain more than $13 \%$ of the variation.

Since the smaller municipalities, to a lesser degree than the larger ones, involve children and youth in planning, it is a method which might be relevant to apply. Therefore, it is important to highlight the strengths and weaknesses of this innovative method for involving children and youth.

\subsection{Discussing the Strengths and Weaknesses of the Children Track Methodology}

How then, can the Children Track methodology be assessed? Lately, many case-studies of different planning processes using Children's Track have been conducted, which we will use, along with our data material, to discuss the contribution of this innovative method. We also want to elaborate on some of the pitfalls of this method.

Experiences from DogA's pilot-project in Bod $\varnothing$, Giske, and Ski are used as cases in our study. Bod $\varnothing$ and Ski are medium-sized cities (51 000 and 29000 inhabitants, respectively) while Giske is a small municipality of 8000 inhabitants. The case-municipalities show that the method can be applied in a broad range of planning processes; in overall plans and more detailed plans, in general plans and more thematic plans. Often it is used to gain citizen knowledge that feeds into the general knowledge base of the municipality.

Many of the studies show that the methodology leads to greater confidence in the planning processes and procedures. The leaders of the Bod $\varnothing$, Giske and Ski pilots (from the March 2016 final seminar) pointed out that Children Track led to better and more democratic planning processes, and that the pilot attempts were a lesson in democracy, both for municipal employees and for schools and the pupils themselves. In two municipalities, it also had a domino effect and stimulated other interventions. The municipalities experienced that more voices were heard in the planning process, which they considered to be an important norm for planning, and 
Table 1. OLS regression analyses of the use of the children track method. Source: Barnetråkk (children's track).

\begin{tabular}{|c|c|c|c|c|c|c|}
\hline \multicolumn{7}{|c|}{ Coefficients } \\
\hline \multirow[b]{2}{*}{ Model } & \multicolumn{2}{|c|}{ Unstandardised Coefficients } & \multirow{2}{*}{$\begin{array}{l}\text { Standardised Coefficients } \\
\text { Beta }\end{array}$} & \multirow[b]{2}{*}{$\mathrm{t}$} & \multirow[b]{2}{*}{ Sig. } & \\
\hline & B & Std. Error & & & & \\
\hline \multirow[t]{8}{*}{1} & (Constant) & $-1,371$ & 1,433 & &,- 957 & ,340 \\
\hline & Municipal size-grouped & ,505 & 160 & ,234 & 3,150 & ,002 \\
\hline & $\begin{array}{l}\text { 9: To what extent do you } \\
\text { (your municipality) need } \\
\text { supervision when conducting } \\
\text { participatory processes? }\end{array}$ & ,098 & 103 & ,073 & ,953 & ,342 \\
\hline & $\begin{array}{l}\text { 10: How confident are you/your } \\
\text { municipality in conducting } \\
\text { participatory processes? }\end{array}$ & ,077 & 142 & ,049 & ,543 & ,588 \\
\hline & $\begin{array}{l}\text { 4: To what extent does your } \\
\text { municipality have the } \\
\text { competence to conduct } \\
\text { participatory processes? }\end{array}$ & ,788 & ,369 & 183 & 2,135 & ,034 \\
\hline & $\begin{array}{l}\text { 6: How often does your } \\
\text { municipality involve citizens } \\
\text { in overall municipal plans? }\end{array}$ & ,232 & 144 & 147 & 1,609 & 109 \\
\hline & $\begin{array}{l}\text { 7: How often does your } \\
\text { municipality involve citizens } \\
\text { in detailed regulation plans? }\end{array}$ &,- 192 & 110 &,- 148 & $-1,744$ & 083 \\
\hline & Adjusted R Square & 130 & & & & \\
\hline
\end{tabular}

Note: Coefficients dependent variable: 11.15.

the children themselves felt like they were able to influence their surroundings, affecting decision makers.

The method clearly represents an important tool for channelling the local knowledge of children and youth in many of the cases that are studied, a group they are experiencing is difficult to obtain otherwise (Aune, Olimstad, Refseth, \& Zamudio, 2015; Hegna, 2017; Martinsen, 2018). Bod $\varnothing$, Giske, and Ski pilots report that they gained increased knowledge of the children's use of their neighbourhoods, which helped to illuminate potential consequences of the plans. Visualisation also provided a basis for new thinking about the use of the area.

Our data also shows that the method is functioning as a translation of tacit knowledge to explicit knowledge (Nonaka \& Takeuchi, 1995). The actors in the municipalities show that the translation from silent knowledge to explicitly mapped knowledge actually makes the concerns the children bring forward become clear and gain weight. The method thus captures a unique, tacit knowledge from the child's own experiences turning it into "explicit" knowledge after Nonaka and Takeuchi's (1995) vocabulary. An informant from one of the casemunicipalities stated: "If we had Children's Track earlier, we had gained greater weight in dialogue with builders on the conservation of 100-meter $\mathrm{cog}$, in the detailed regulation of this specific project" (Municipal employee, personal communication).
The children's use and perception of their everyday spatial surroundings is translated into the language of the planners, i.e., maps. Visualisation through symbol usage on maps is important as a political language, and when they are aggregated, they reveal physical patterns (as shown in Figures 4 and 5 ). In this manner, they get acquainted with children's use of the local community early in the planning process, which provides better conditions for ensuring good living environments and safe surroundings. The municipalities also report that policy areas such as public health and culture, which traditionally do not have routines for using maps in their work, also benefit from the Children Track Methodology (Hovden, 2016). Thus, when the tacit knowledge is translated into explicit knowledge (registrations on maps), they are translated into the language of planners. Thereby, planners that were interviewed considered the information to be easy to include directly into the planning documents. As is stated in the final report from one of the casemunicipalities: "The advantage is that the results are available as maps in the municipality's map service" (Ski Municipality, 2016). Cele and van der Burgt (2015) argue that models based on GIS (geographical information systems) and maps are a way for children to be able to express their views on their local environment. However, it requires that the models not only be child-friendly and school-friendly, but also planner-friendly. If it is not 
electronic, not believed to provide relevant information in a smart format, or not easy to combine with other planning documents, it is often not considered (Cele \& van der Burgt, 2015). If the planner does not know how to interpret the information, it is a risk that an adultrepresentation will take over.

Some studies also show how citizen knowledge has had an impact on local policy and planning outputs. The information contributes to the fact that the actual design of children's local environment (development projects, street environments, green structures, parks) can be more adapted to children's needs (and children of all ages) and to achieve a more appropriate area development for a broader range of goals. In one of the cases (Martinsen, 2018), as a consequence of better knowledge about the children's use of the area, an area was regulated to play-ground and green-structure instead of parking.

Experience also shows that childhood registrations are often a gateway to interdisciplinary and (wholeminded) work around children within the municipal organisation. Thus, it contributes to enforce a comprehensive child focus in municipal planning and administration at schools, day care centres, child welfare, PP office, health services, social service office, sports, and more. An informant from a case-municipality stated that the method had contributed to creating better cooperation between the municipal school department and the planning department.

All three case-municipalities emphasise that anchoring the municipal administration is crucial in achieving a greater understanding of children's perception of the local community through Children's Track. In the interviews, it appears that the biggest challenge is to cooperate with the schools, as the Children's Track registrations are often conducted in the classroom with the help of their teacher and a planner. Having support from the chief executive in the municipality is important in order to convince the principals of the schools that it is worth taking some hours to carry out the registrations. In addition, political anchoring is important, especially if the method is to be institutionalised as a cooperation between the school department and the planning department in the municipality. It also provides a process-procedure; a spatial plan has deadlines, project group, procedures for informing politicians, etc. Implementation of Children's Track requires that the school collaborate in conducting the registrations. This means that principals, teachers, and the municipality's management must benefit from it. In order to work out this acceptance, great involvement is required; especially if the Children Track registrations should be a regular routine since knowledge is a form of "fresh food". Also in Bringeland (2017, p. 73) and Martinsen (2018), it is emphasised that the registrations must be updated to be used so that different actors can rely on the information.

The final report from Ski Municipality (2016) states that the method has strengthened the strategic attach- ment of children and young people's participation in the municipality:

Ski politicians have now in their cooperation platform for the period 2015-2019 stated that children and young people should have increased political influence. They want children and young people to have a clear voice in the development of society, and children and young people should be involved in matters that concern them in particular. The use of Children's Track in planning cases must be continued. It is likely that the results (urban development) will be better. Participation may initially take time in a planning process. The completion of a planning process may be improved if the content of the plan has better support for the population.

Hanssen and Aarsæther (2018a, 2018b) show that digital maps and municipal plan archives have been strengthened as plan tools (Rutledal, 2017). This requires an identification of what type of information is possible to illustrate on maps and the limitations of the graphic language of maps. Planners must, therefore, be aware of the weaknesses of the methods. One of the most important weaknesses is that the methodology reduces the "dense" silent knowledge of the children's experience of the place into narrow map-expressed "explicit" information. As a planner states: "The disadvantage of Children's Track method is that it does not involve direct dialogue with the children and that some information is missing" (Ski Municipality, 2016). Thus, the Children Track registrations should always include a planner that is present in the classrooms during the registrations. By doing this, the planner will be able to obtain more of the "rich" histories that are told by the children while they are doing the registrations. They are able to obtain the "silent" knowledge that appears in children's conversations. Related research literature reminds us that there are experiences about being a child and relating to the environment that can and should only be told by a child (Knowles-Yánez, 2005).

The idea is that the information from the registrations should be aggregated (to ensure anonymity) and shown on a map which is open for the public and other stakeholders. Informants in our study outside these municipalities are worried about how private developers can use the knowledge produced by "children's track" against the interests of children. One of the examples was from another municipality that had used the methods. There, private developers studied the maps and used them to argue why they should be allowed to build in a green area that was not so frequently used by children.

Other studies also show that the method, to a small extent, allows children's own creativity to play out, for example, in the preparation of proposals for projects (Aune et al., 2015). The method is largely shaped in the perspective of adults. However, the advantage of the 
methodology is that it captures some aspects of children's experience, converting it into a more graphically manufacturing-friendly knowledge type that is relatively easy to integrate into project documents. The map format is, however, not a form of dissemination that hits everyone-especially not the wide range of citizens.

Hence, the discussion has shown that the innovative method of Children's Track Methodology has several strengths, and a huge potential to increase the level of children's participation in planning. This is especially important in small municipalities, which to a lesser degree than larger ones, involve children systematically. However, the strengths of the method, that it reduces thick, tacit knowledge into thin, explicit knowledge expressed by maps, is also its weakness. Much information and local knowledge are lost on the way that might be obtained by more time-consuming methods like charrettes and dialogue meetings.

\section{Concluding Discussion}

As Simpson (1997) emphasises, once it is accepted that urban planning has an important effect on the lives of citizens-including children, it follows that the process by which decisions are taken about such matters becomes crucial. This is where law and urban planning most obviously intersect. In Norway, where national planning regulation for many years has aimed at stimulating a development that ensures active urban childhoods. In order to ensure this, the PBA ensure particular participation rights for children and youth in the planning process. However, in practice, most land use planning practices today exclude children, in Norway as in other countries (Knowles-Yánez, 2005), thereby losing important local knowledge, as well as the opportunity to educate children about land use decision-making processes and democratic procedures. According to Goodyear and Checkoway (2003), participation in planning processes allows young people the opportunity to assert their political rights as they bring their youth and locale-based knowledge to bear on decision-making processes.

In Norway, even if a large proportion of the Norwegian municipalities report that they have "children's representatives" (an adult), much fewer report about direct representation in decision-making processes. The article has shown that even in a country where children's right in planning has been institutionalised in over 30 years, there is still great variation between municipalities in how they ensure them in practice. Larger municipalities are better than smaller ones at involving children in a systematic way. The institutional settings have triggered some social innovation locally, and we have studied one of them: the children's track method. The method has several strengths, and a huge potential to increase the level of children's participation in planning. In addition, it maps the children's activities and experiences of urban space. In Fagerholm and Brobergs' (2011) study on Finnish children, they used similar map-based tools (GPS tracking), but also mobility diaries, interviews, and questionnaires, observed a high level of independent mobility, suggesting positive developments in children's wellbeing. The generally high level of independence is related to the high perception of safety, both from the children's and the parent's perspective, in the residential areas. In the UK, Mackett et al. (2007) shows by similar studies that, when not in adult company, children tend to be physically more active and to walk more complicated routes. Thus, this suggests that urban space must be designed to allow the independent mobility of children and increase public health. Another study (Hume, Salmon, \& Ball, 2005) asked 147 ten-year-old children to draw maps of their local neighbourhood. Here, the importance of social interaction was highlighted, as they highlighted the locations in the neighbourhood that were common meeting places for them and their friends. Thus, a participatory approach to the planning and design of the public realm is central to the creation of an inclusive environment (Haider, 2007).

However, the challenge of these map-based methods is that it reduces thick, tacit knowledge into thin, explicit knowledge expressed by maps. Much information and local knowledge are lost on the way, which might otherwise be obtained by more time-consuming methods like charrettes and dialogue meetings.

Other studies find that including children in planning processes (Alparone \& Rissotto, 2001) has positive effects on the child's personal and social development and factors that are seen to be relevant to success are discussed. In order to achieve this, it requires that the child is recognised as competent and as a social actor with agency to participate in their social and cultural context (Cele \& van der Burgt, 2015). However, Cele and van der Burgt (2015) argue that it is important to ask when participation is beneficial and meaningful for those involved. The study of Fagerholm and Broberg (2011) finds that the independent mobility pattern is tied to the home and school areas. The paradox, however, is that newer residential areas commonly tend to have a lack of community infrastructure, which is needed to provide opportunities for children, or families with young children, to interact with other families (Strange, Fisher, Howat, \& Wood, 2015). Opportunities for outdoor play and independent mobility are found to be quite limited for many children (Boreham \& Riddoch, 2001; Veitch, Bagley, Ball, \& Salmon, 2006). Our study also reveals a lack of consciousness in ensuring the concerns for children and youth in planning in smaller municipalities. Thus, urban planning needs to provide infrastructure and public space that encourage young children to connect and build social capital within their local communities.

\section{Acknowledgments}

This study has been conducted in a research project evaluating the Norwegian Planning and Building Act, financed by the DEMOSREG-programme in the Norwegian 
Research Council. In addition, it has been financed by an extra funding from the Norwegian Ministry of Local Government and Modernization.

\section{Conflict of Interests}

The author declares no conflict of interests.

\section{References}

Alparone, F. R., \& Rissotto, A. (2001). Children's citizenship and participation models: Participation in planning urban spaces and children's councils. Journal of Community \& Applied Social Psychology, 11(6), 421-434.

Arup. (2017). Cities alive. Designs for urban childhoods. London: Arup.

Aune, M., Olimstad, M., Refseth, M. S., \& Zamudio, U. H. (2015). Children's Tracks: Advancing children's rights to participate in land-use planning? In ECTPCEU (Ed.), E-government \& spatial planning decisionmaking. Young Planners workshop 2015. 11th biennial of European towns \& town planners (pp. 86-99). Dublin: ECTP-CEU.

Baldersheim, H., \& Rose, L. (2014). Det kommunale laboratorium [The municipal laboratory]. Bergen: Fagbokforlaget.

Boreham, C., \& Riddoch, C. (2001). The physical activity, fitness and health of children and health. Journal of Sports Sciences, 19(12), 915-929.

Bringeland, L. (2017). Barn og unges involvering og innflytelse i den kommunale planleggingen: En kvalitativ casestudie i Sandnes kommune [The involvement and influence of children and youth in municipal planning: A qualitative case-study of the municipality of Sandnes] (Unpublished Master thesis). University of Life Science.

Bugge, H. C. (2016). Norge som lavutslippssamfunn. Hvordan utvikle plan- og bygningsloven som klimapolitisk virkemiddel? [Norway as a low-carbon society. How to develop the Norwegian Planning and Building Act as a climate-political tool?] (Report to the Norwegian Ministry of Local Government and Modernization). Oslo.

Buss, S. (1994). Children and the urban spatial environment: Meaning and action from young people's angle of vision (Unpublished Doctoral dissertation). Los Angeles, CA: University of California Los Angeles.

Cele, S., \& van der Burgt, D. (2015). Participation, consultation, confusion: Professionals' understandings of children's participation in physical planning. Children's Geographies, 13(1), 14-29.

Derr, V. (2015). Integrating community engagement and children's voices into design and planning education. CoDesign, 11(2), 119-133.

Derr, V., \& Tarantini, E. (2016). “Because we are all people": Outcomes and reflections from young people's participation in the planning and design of child- friendly public spaces. Local Environment, 21(12), 1534-1556.

Education Act 1998 (Norway). Retrieved from lovdata.no /dokument/NL/lov/1998-07-17-61?q=opplæringslov

Fagerholm, N., \& Broberg, A. (2011). Mapping and characterising children's daily mobility in urban residential areas in Turku, Finland. Fennia, 189(2), 31-46.

Freeman, C., \& Tranter, P. (2011). Children and their urban environment: Changing worlds. London: Earthscan.

Fung, A., \& Wright, E. O. (2001). Deepening democracy: Innovation in empowered participatory governance. Politics and Society, 29(1), 5-41.

Gehl, J. (1971). Livet mellom husene [Life between buildings]. Copenhagen: Arkitektens forlag.

Gehl, J. (2010). Byen for mennesker [Making cities for people]. Copenhagen: Bogværket.

Gill, T. (2018). Reviving neighbourhoods: Case studies of child-friendly urban planning and design in Europe and Canada. Report in preparation.

Giske Municipality. (2018). Smart bruk av barnetråkk in Giske Kommune [Smart use of Children's Track in Giske municipality]. My News Desk. Retrieved from www.mynewsdesk.com/no/geodata-as/news/smartbruk-av-barnetraakk-i-giske-kommune-153144?utm_ source=Kommune\%20nyhetsbrev\%20\&utm_medium =Nyhetsbrev\&utm_content=Nyhetsbrev\%20februar \&utm_campaign=Nyhetsbrev\%20kommune

Goodyear, L. K., \& Checkoway, B. (2003). Notes from the editor: Establishing the importance of youth participation in community evaluation and research. Community Youth Development Journal, 4(1), 5.

Haider, J. (2007). Inclusive design: Planning public urban spaces for children. Municipal Engineer, 160(2), 83-88.

Hanssen, G. S. (2013). Negotiating urban space. Challenges of legitimacy in market-oriented urban planning (Unpublished Doctoral dissertation). Oslo: University of Oslo.

Hanssen, G. S. (2018). Ivaretas barn og unge i planlegging etter pbl? [Do local planning ensures the concerns and needs of children and youth?]. In G. S. Hanssen \& N. Aarsæther (Eds.), Plan-og bygningsloven 2008: En lov for vår tid? [The Norwegian Planning and Building Act: A law for our time?] (pp. 277-306). Oslo: Universitetsforlaget.

Hanssen, G. S., \& Aarsæther, N. (2018a). Plan- og bygningsloven 2008: Fungerer loven etter intensjonene? [The Norwegian Planning and Building Act: Does the Act function as intended?]. Oslo: Universitetsforlaget.

Hanssen, G. S., \& Aarsæther, N. (2018b). Plan- og bygningloven 2008: En lov for vår tid? [The Norwegian Planning and Building Act: A law for our time?] Oslo: Universitetsforlaget.

Hanssen, M. (2006). Rikspolitiske retningslinjer for barn og unge. En evaluering [National guidelines for children and youth in planning. An evaluation] (NIBR Re- 
port 2006: 127). Oslo: NIBR.

Hegna, I. A. (2017). Hvilke medvirkningsverktøy- og metoder brukes i norske kommuner og hvordan fungerer de? [Which types of methodology do Norwegian municipalities use, and how do they function?] (DogA Report). Oslo: DogA.

Henriksen, S. G. (2014). Barn og unges medvirkning $i$ planprosesser gjennom Ungdomsråd-En kvalitativ casestudie av to norske kommuner [The participation of children and youth in planning: A qualitative case-study of two Norwegian municipalities] (Unpublished Master dissertation). NMBU, University of Life Science.

Hofstad, H. (2018). Folkehelse-Et proaktivt grep I Pbl 2008. Hva er status ti år etter? [Health promotion: A proactive strategy in the Norwegian Planning and Building Act 2008. What is the status ten years later?] In G. S. Hanssen, \& N. Aarsæther (Eds.), Plan-og bygningsloven 2008-En lov for vår tid? [The Norwegian Planning and Building Act: A law for our time?] (pp. 223-240). Oslo: Universitetsforlaget.

Hovden, E. (2016). Erfaringer med barnetråkk i Ski kommune [Experiences from using the Children's Track methodology in Ski municipality]. Paper presented at Oslo.

Hovind, A. K. (2014). Utemiljø for barn og unge i Jessheim sentrum [Outdoor environment for children and youth in the town-centre of Jesseim] (Unpublished Master thesis). Ås: University of Life Science.

Hume, C., Salmon, J., \& Ball, K. (2005). Children's perceptions of their home and neighborhood environments, and their association with objectively measured physical activity: A qualitative and quantitative study. Health Education Research, 20(1), 1-13.

Klausen, J.-E., Arnesen, S., Christensen, D. A., Folkestad, B., Hanssen, G. S., Winsvold, M., \& Aars, J. (2013). Medvirkning med virkning? Innbyggermedvirkning $i$ den kommunale bes/utningsprosessen [Participation with Influence? Citizen-involvement in Local decisionmaking] (Cooperation Report NIBR/ Uni Rokkansenteret). Oslo: NIBR.

Impact Assessment Regulation. (2017). Forskrift om konsekvensutredninger [Impact assessment regulation]. Lovdata.no. Retrieved from lovdata.no/dokument/ SF/forskrift/2017-06-21-854

Knowles-Yánez, K. L. (2005). Children's participation in planning processes. Journal of Planning Literature, 20(1). https://doi.org/10.1177/0885412205277032

Knudtzon, L., \& Tjerbo, T. (2009). De unge stemmene. Innflytelsesorgan for barn og unge i kommuner og fylker [The young voices. Organised channels of influence for children and youth in local government]. (NIBR Report 2009:34). Oslo: NIBR.

Lynch, K. (1977). Growing up in cities. Cambridge, MA: MIT Press.

Mackett, R., Banister, D., Batty, D., Einon, D., Brown, B., Gong,Y., Kitazawa, K., Marshall, S., \& Paskins, J. (2007). Final report on 'children's activities, percep- tions and behaviour in the local environment (CAPA$B L E)$. London: University College London.

Martinsen, C. (2018). Decoration or participation? Children's Tracks and the zoning planning of an area undergoing development and densification (Unpublished Master thesis). Ås: University of Life Science.

Ministry of Environment. (2009). Temaveileder: Barn og unge og planlegging etter plan-og bygningsloven [Guidelines: How to ensure the concerns of children and youth in planning processes according to the Norwegian Planning and Building Act?]. Oslo: The Ministry of Environment.

Meld. St. 28. (2016). Fag: Fordypning-Forståelse-En fornyelse av kunnskapsløftet [Disciplines, understanding: Renewal of the governmental program of strengthening the knowledge in the school sector] (White Paper). Government Norway. Retrieved from www.regjeringen.no/no/dokumenter/meld.-st.-2820152016/id2483955/sec1

Nonaka, I., \& Takeuchi, H. (1995). The knowledge creative company: How Japanese companies create the $d y$ namic of innovation. Oxford: Oxford University Press.

NOU. (2001). Bedre kommunal og regional planlegging etter plan- og bygningsloven I [Better local and regional planning according to the Norwegian Planning and Building Act I] (White Paper NOU 2001:7). Government Norway. Retrieved from www.regjeringen. no/no/dokumenter/nou-2001-7/id143492/sec1

NOU. (2003). Bedre kommunal og regional planlegging etter plan- og bygningsloven II [Better local and regional planning according to the Norwegian Planning and Building Act II] (White Paper 2003:14). Government Norway. Retrieved from www.regjeringen.no/ no/dokumenter/nou-2003-14/id382097

NOU. (2015). Fremtidens skole-Fornyelse av fag og kompetanser [The future school: Renewal of disciplines and competence] (White Paper 2015:8). Government Norway. Retrieved from www.regjeringen.no/en/ find-document/norwegian-official-reports/id1767

Proposition 32. (2008). Om lov om planlegging og byggesaksbehandling (plan- og bygningsloven). [About the Norwegian Planning and Building Act: The planning part] Norwegian government. Retrieved from www.regjeringen.no/no/dokumenter/otprp-nr32-2007-2008-/id500508

Pateman, C. (1970). Participation and democratic theory. Cambridge: Cambridge University Press.

Planning and Building Act 2008 (Norway). Retrieved from www.regjeringen.no/en/dokumenter/planning-build ing-act/id570450

Rutledal, B. (2017). Tegnereglene i norsk planleggingHistorie, praksis, forståelse [The drawing rules in Norwegian planning: History, practice, understanding] (Unpublished Master thesis). NMBU, University of Life Science.

Scharpf, F. (1999). Governing in Europe: Effective and democratic? Oxford: Oxford University Press.

Simpson, B. (1997). Towards the participation of children 
and young people in urban planning and design. Urban Studies, 34(5/6), 907-925.

Ski municipality. (2016). Presentation of the "children's track pilot". Oslo: DogA.

Strange, C., Fisher, C., Howat, P., \& Wood, L. (2015). Creating a village in modern suburbia: Parenthood and social capital. Urban Policy \& Research, 33(2), 160-177.

Stray, J. (2014). Skolens demokratimandat [School's democracy mandate]. In J. Stray \& L. Wittek. Pedagogikk: En grunnbok [Pedagogy: An introduction] (pp. 651-663). Oslo: Cappelen Damm Akademisk.

UN. (1989). United Nations Convention on the Rights of the Child. New York, NY: United Nations.

UNICEF. (2014). Child-friendly cities initiative. Retrieved from childfriendlycities.org

Veitch, J., Bagley, S., Ball, K., \& Salmon, J. (2006). Where do children usually play? A qualitative study of parents' perceptions of influences on children's active free-play. Health \& Place, 12(4), 383-393.

Vestby, G. M., \& Ruud, M. E. (2012). Ungdom og lokal samfunnsutvikling. Hvordan involveres ungdom på fylkeskommunalt nivå [Youth and place-making. How are the youth involved in decision-making at regional level?]. (NIBR Report 2012: 16). Oslo: NIBR.

Wilks, J., \& Rudner, J. (2013). A voice for children and young people in the city. Australian Journal of Environmental Education, 29(1), 1-17.

Woolley, H., Dunn, J., Spencer, C., Short, T., \& Rowley, G. (1999). Children describe their experience with the city centre: A qualitative study of the fears and concerns which might limit their full participation. Landscape Research, 24, 287-301.

\section{About the Author}

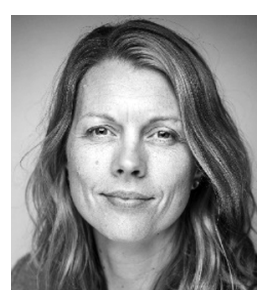

Gro Sandkjaer Hanssen is a Senior Researcher at the Norwegian Institute for Urban and Regional Research at Oslo Metropolitan University, and Professor at the Department of Urban and Regional Planning at the University of Life Science, Norway. Her research interests are urban planning, participatory planning, local democracy, and multi-level governance. Over the last years, she has led research projects pertaining to the Norwegian Planning and Building Act, climate change adaptation, and democratic public space. 